\title{
Shrinking the room for invasive ventilation in hypercapnic respiratory failure
}

This article was published in the following Dove Press journal:

International Journal of COPD

14 March 2013

Number of times this article has been viewed

\section{Paolo Scarpazza' \\ Cristoforo Incorvaia ${ }^{2}$ \\ Chiara Melacini' \\ Roberta Cattaneo' \\ Cristiano Bonacina' \\ Gian Galeazzo Riario- \\ Sforza ${ }^{2}$ \\ Walter Casali'}

'Pneumology Unit, Ospedale Civile, Vimercate, ${ }^{2}$ Pulmonary Rehabilitation, Istituti Clinici di Perfezionamento, Milan, Italy
Correspondence: Cristoforo Incorvaia Viale Molise 6, 20137 Milan, Italy

Tel +392 55I 3852

Fax +39257993315

Email cristoforo.incorvaia@gmail.com
Abstract: Noninvasive ventilation (NIV) was introduced as an alternative to invasive mechanical ventilation for acute respiratory failure caused from exacerbations of chronic obstructive pulmonary disease in the 1980 s, and its use gradually rose worldwide. Seventy-eight patients (57 males, mean age $78.3 \pm 9.2$ years) undergoing NIV were evaluated. Of them, 48 (62.3\%) had acute hypercapnic respiratory failure because of a chronic obstructive pulmonary disease exacerbation, and the remaining 30 had acute hypercapnic respiratory failure from other causes, mainly cardiac failure. All patients were treated by NIV using the bi-level positive airway pressure set up at high pressure/high backup rate. NIV was successful in 67 subjects $(85.9 \%)$ and the patients were discharged, 57 of whom continued NIV at home and ten had spontaneous breathing. NIV was unsuccessful in eleven patients, ten of whom died and one was successfully treated by invasive mechanical ventilation. Significant differences were detected for a higher basal Glasgow Coma Scale score in successfully treated patients $(P=0.007)$, a higher basal Acute Physiology and Chronic Health Evaluation score in unsuccessfully treated patients $(P=0.004)$, and a lower $\mathrm{pH}$ after 1 hour in unsuccessfully treated patients $(P=0.015)$. These findings show a very high rate of success of NIV in patients with acute hypercapnic respiratory failure not only from chronic obstructive pulmonary disease but also from cardiac failure. This suggests that the use of invasive mechanical ventilation may be further reduced, with a decrease in its known complications as well.

Keywords: invasive ventilation, noninvasive ventilation, acute respiratory failure

\section{Introduction}

The use of invasive mechanical ventilation by endotracheal intubation in acute respiratory failure is long known. ${ }^{1}$ Noninvasive ventilation (NIV) began to be considered as an alternative to invasive mechanical ventilation in acute respiratory failure caused from exacerbations of chronic obstructive pulmonary disease (COPD) in the 1980s, and its use gradually rose worldwide. In 1998, an international prospective survey reported that about one-third of patients initially treated with NIV had to undergo endotracheal intubation, ${ }^{2}$ but 6 years later another large international prospective study reported a better outcome. ${ }^{3}$ Also, NIV effectiveness is supported by results of systematic reviews, ${ }^{4}$ and this has led to an increase in the application of this treatment, even in complicated situations such as a do-not-intubate order in elderly patients. ${ }^{5}$ However, in 2010, Manuel et al reasoned that "there is little convincing evidence for the use of NIV in severe, but stable COPD" and that "what is less clear, however, is the quality of how NIV is delivered to patients." ${ }^{2}$ Indeed, a recent study focused its attention on the kind of NIV setup, which can be based on high inflation pressure and high backup rate 
(high-intensity NIV) or high pressure and low backup rate (high-pressure NIV). The authors reported that the pivotal role in managing by NIV hypercapnic respiratory failure in COPD patients is the high-pressure component. ${ }^{7}$

\section{Results}

Seventy-eight patients ( 57 males, mean age $78.3 \pm 9.2$ years) undergoing NIV were evaluated. Of them, 48 (62.3\%) had acute hypercapnic respiratory failure because of a COPD exacerbation and the remaining 30 had acute hypercapnic respiratory failure from other causes, mainly cardiac failure. All patients were treated by NIV using the bi-level positive airway pressure set up at high pressure/high backup rate. NIV was successful in 67 subjects $(85.9 \%)$ and the patients were discharged, 57 of whom continued NIV at home and ten were in a state of spontaneous breathing. NIV was unsuccessful in eleven patients, ten of whom died and one was successfully treated by invasive mechanical ventilation. The mean age of successfully treated $(77.7 \pm 9.4$ years $)$ and unsuccessfully treated $(82.1 \pm 8.1$ years $)$ patients was not significantly different. Table 1 reports the characteristics of the two groups of patients. Significant differences were detected for a higher basal Glasgow Coma Scale score in successfully treated patients $(P=0.007)$, a higher basal score of the Acute Physiology and Chronic Health Evaluation score in unsuccessfully treated patients $(P=0.004)$, and a lower $\mathrm{pH}$ after 1 hour in unsuccessfully treated patients $(P=0.015)$.

\section{Discussion}

Among the risk factors for failure of NIV, the $\mathrm{pH}$ value seems particularly important ${ }^{8}$ which corresponds with the

Table I Considered parameters in patients responding or not to noninvasive ventilation

\begin{tabular}{|c|c|c|}
\hline & $\begin{array}{l}\text { Patients } \\
\text { responding to NIV } \\
(n=67)\end{array}$ & $\begin{array}{l}\text { Patients not } \\
\text { responding to NIV } \\
(\mathrm{n}=\mathrm{II})\end{array}$ \\
\hline GCS score & $9.7 \pm 2.9$ & $7.2 \pm 1.5$ \\
\hline APACHE score & $28.9 \pm 4.7$ & $33.2 \pm 2.9$ \\
\hline $\mathrm{pO}_{2} / \mathrm{FiO}_{2}$ & $174.8 \pm 44.9$ & $156.5 \pm 40.1$ \\
\hline $\mathrm{PCO}_{2}$ & $98.9 \pm 14.6$ & $98.2 \pm 15.5$ \\
\hline $\mathrm{pH}$ & $7.13 \pm 0.1$ & $7.11 \pm 0.1$ \\
\hline $\mathrm{pO}_{2} / \mathrm{FiO}_{2}$ after I hour & $175.3 \pm 70.6$ & $160.8 \pm 48.2$ \\
\hline $\mathrm{PCO}_{2}$ after I hour & $75.4 \pm 14.8$ & $81.4 \pm 25.8$ \\
\hline $\mathrm{pH}$ after I hour & $7.25 \pm 0.08$ & $7.18 \pm 0.12$ \\
\hline $\mathrm{PO}_{2} / \mathrm{FiO}_{2}$ after 12 hours & $198.1 \pm 81.6$ & $185.9 \pm 94.2$ \\
\hline $\mathrm{PCO}_{2}$ after 12 hours & $59.6 \pm 11.1$ & $58.3 \pm 7.6$ \\
\hline $\mathrm{pH}$ after 12 hours & $7.36 \pm 0.06$ & $7.37 \pm 0.04$ \\
\hline
\end{tabular}

Abbreviations: APACHE, Acute Physiology and Chronic Health Evaluation; $\mathrm{FiO}_{2}$, fraction of inspired oxygen; GCS, Global Coma Scale; NIV, noninvasive ventilation; $\mathrm{pCO}_{2}$, carbon dioxide partial pressure; $\mathrm{pO}_{2}$, oxygen partial pressure. current data. Also, the Acute Physiology and Chronic Health Evaluation confirmed the predictive value of a score higher than 29, which was detected in patients with a negative outcome. Overall, the current data, obtained in a pneumology unit, show that NIV is able to manage the large majority of patients $(86 \%)$ with acute respiratory failure from COPD exacerbations and also from other causes. A randomized study found that the use of NIV as rescue therapy was associated with a lower number of patients meeting the endotracheal intubation criteria and with a lower mortality rate compared with endotracheal intubation. ${ }^{9}$ The factors underlying a negative outcome of NIV warrant investigation in studies in large populations of patients. In particular, the impact of comorbidities is an important issue. A recent study reported that patients with COPD and obesity hypoventilation syndrome treated with NIV because of acute hypercapnic respiratory failure had a response to treatment similar to patients with only COPD. ${ }^{10}$ Moreover, a low rate of endotracheal intubation need was recently reported in patients with acute respiratory failure from heart failure treated with NIV, ${ }^{11}$ and this observation is pertinent for the patients in the current study.

\section{Conclusion}

The findings show a very high rate of success of NIV in patients with acute hypercapnic respiratory failure from COPD as well as from other causes, including cardiac failure. This suggests that the use of invasive mechanical ventilation may be further reduced, with a decrease in its known complications as well.

\section{Acknowledgment}

The authors thank Miss Laura Shearer for language revision.

\section{Disclosure}

The authors report no conflicts of interest in this work.

\section{References}

1. Wilson RS, Pontoppidan H. Acute respiratory failure: diagnostic and therapeutic criteria. Crit Care Med. 1974;2(6):293-304.

2. Esteban A, Anzueto A, Frutos F, et al. Characteristics and outcomes in adult patients receiving mechanical ventilation: a 28 -day international study. JAMA. 2002;287(3):345-355.

3. Esteban A, Ferguson ND, Meade MO, et al. Evolution of mechanical ventilation in response to clinical research. Am J Respir Crit Care Med. 2008;177(2):170-177.

4. Keenan SP, Sinuff T, Cook DJ, Hill NS. Does noninvasive positive pressure ventilation improve outcome in acute hypoxemic respiratory failure? A systematic review. Crit Care Med. 2004;32(12):2516-2523.

5. Scarpazza P, Incorvaia C, di Franco G, et al. Effect of noninvasive mechanical ventilation in elderly patients with hypercapnic acute-onchronic respiratory failure and a do-not-intubate order. Int $J$ Chron Obstruct Pulmon Dis. 2008;3(4):797-801. 
6. Manuel A, Russell RE, Jones Q. Noninvasive ventilation: has Pandora's box been opened? Int J Chron Obstruct Pulmon Dis. 2010;5: 55-56.

7. Murphy PB, Brignall K, Moxham J, Polkey MI, Davidson AC, Hart N. High pressure versus high intensity noninvasive ventilation in stable hypercapnic chronic obstructive pulmonary disease: a randomized crossover trial. Int J Chron Obstruct Pulmon Dis. 2012;7:811-818.

8. Confalonieri M, Garuti G, Cattaruzza MS, et al. A chart of failure risk for noninvasive ventilation in patients with COPD exacerbation. Eur Respir J. 2005;25(2):348-355.
9. Nava S, Grassi M, Fanfulla F, et al. Non-invasive ventilation in elderly patients with acute hypercapnic respiratory failure: a randomised controlled trial. Age Ageing. 2011;40(4):444-450.

10. Carrillo A, Ferrer M, Gonzalez-Diaz G, et al. Noninvasive ventilation in acute hypercapnic respiratory failure caused by obesity hypoventilation syndrome and chronic obstructive pulmonary disease. Am J Respir Crit Care Med. 2012;186(12):1279-1285.

11. Yamamoto $\mathrm{T}$, Takeda $\mathrm{S}$, Sato $\mathrm{N}$, et al. Noninvasive ventilation in pulmonary edema complicating acute myocardial infarction. Circ J. 2012;76(11):2586-2591.

International Journal of COPD

\section{Publish your work in this journal}

The International Journal of COPD is an international, peer-reviewed journal of therapeutics and pharmacology focusing on concise rapid reporting of clinical studies and reviews in COPD. Special focus is given to the pathophysiological processes underlying the disease, intervention programs, patient focused education, and self management protocols.

\section{Dovepress}

This journal is indexed on PubMed Central, MedLine and CAS. The manuscript management system is completely online and includes a very quick and fair peer-review system, which is all easy to use. Visit $\mathrm{http}: / /$ www.dovepress.com/testimonials.php to read real quotes from published authors.

Submit your manuscript here: http://www.dovepress.com/international-journal-of-copd-journal 